BOGDAN NOGALSKI

WSB University in Gdańsk, Poland

bogdannogalski.bn@gmail.com

ORCID iD: 0000-0003-0262-8355

ANDRZEJ JÓZEF KOZŁOWSKI

State Higher Vocational School

in Ciechanów, Poland

kozlowskiandrzej54@gmail.com

ORCID iD: 0000-0002-1993-6525
DOI: $10.13166 / j m s / 144217$

JOURNAL OF MODERN

SCIENCE TOM 2/47/2021
Iwona Zofia Czaplicka-KozŁowsKa

University of Warmia and Mazury in Olsztyn,

Poland

iwona.kozlowska@uwm.edu.pl

ORCID iD: 0000-0003-4268-0510

\title{
A RETROSPECTIVE LOOK AT THE REALITY OF CONTEMPORARY PUBLIC MANAGEMENT IN THE OPTICS OF A PARADOX, DILEMMA AND RECOMMENDATIONS OF SOLUTIONS
}

\begin{abstract}
SUMmarY
When analyzing the reality that surrounds us in the field of the common good, we often ask ourselves why we are primarily concerned with the effects and not the causes. Public management is an obvious example of this, especially in the area of it that is referred to as public administration. This area will constitute a point of reference in our considerations. The aims of the article focus on an evolutionary and retrospective look at the reality of contemporary public management in Poland in the second decade of the 21st century and considering the reality of public management in the convention of paradoxes and dilemmas. We are aware of the fact that in this article we are not able to thoroughly analyze all the paradoxes that exist in the reality of contemporary public management and the dilemmas that arise in it. Therefore, we limited the field of analysiwws to a few selected ones related to the functioning of public administration. As a result of the analysis, recommendations were formulated to increase the efficiency of modern public management in Poland.
\end{abstract}

KEYWORDS: retrospection, public management, paradoxes, dilemmas, recommendations for solutions 


\section{INTRODUCTION}

When analyzing the reality around us in terms of the common good, we often ask ourselves why we are primarily concerned with the effects and not the causes. Public management is an obvious example of this, especially in the area of it that is referred to as public administration. This area will constitute a point of reference in our considerations. As Z. Dobrowolski writes, public administration should be efficient in its operation, which means, inter alia, the ability to effectively solve specific social problems thanks to prior recognition of needs and the possibility of satisfying them. It is possible by departing from the imperative approach to solving problems and including various entities included in the environment in which the public administration functions in the process of initiating and implementing tasks, as well as assessing their effects (Dobrowolski, 2013, pp. 127-142). Although the above statement considers it appropriate to look at solving social problems through the prism of causes (departure from the imperative approach ...), the reality is definitely different. In the social reality, in solving social problems, the imperative-effect approach is dominant, expressed in the fact that state officials know best what a citizen needs. Therefore, we consider the examination of the correctness - regularities of contemporary public management in Poland to be a topical, cognitively interesting and socially important issue. We considered it justified to look at the above-mentioned issue in a retrospective manner, basing the narrative in the optics of a paradox and a dilemma. We base our narrative on the method of direct observation and discussion of experts who have been dealing with the efficiency of functioning of public administration for many years, including local and state administration.

The first goal of the article is an evolutionary and, at the same time, retrospective look at the reality of contemporary public management in Poland in the second decade of the 21 st century. This mainly concerns the behaviors and instruments used by contemporary decision-makers that affect the quality and shape of public management.

The second aim of the article is to present the reality of contemporary public management in the convention of paradox and dilemma optics, and to present recommendations increasing the efficiency of modern public management in Poland. 
We are aware of the fact that in this article we are not able to thoroughly analyze all the paradoxes that actually occur in contemporary public management and the dilemmas that they formulate. Therefore, we limited the field of analysis to a few selected problems related to the functioning of public administration. In our opinion, they can serve as a starting point for a deeper discussion. Therefore, we will discuss issues related to:

- revealing the historical context in order to set the problem under consideration against a specific background,

- identification of paradoxes that characterize and isolation of dilemmas modifying contemporary public management; in this cross-section of the analysis, we pay attention to two perspectives: the analysis of the paradox and the analysis of dilemmas accompanying public management in the 21 st century,

- presentation of selected recommendations for solutions to improve public management.

\section{HISTORICAL CONTEXT - THE BACKGROUND OF THE PROBLEM}

Very often, when conducting classes for students, but also in private conversations, we hear many questions relating to the reality around us, especially related to public management (Kożuch, 2005, pp. 40-50) and its influence on people's behavior. The most common questions refer to the changes observed in Poland in recent years - although not only in Poland. Students ask how it is so and not otherwise, pointing to negative examples in managing the state in its internal and external dimensions. At the same time, they expect an answer to the question: where is it going and why are the rulers choosing this and not another path? Children at home ask about the future, where is it worth living, what to do to ensure a peaceful life? Everyone asks for money, where to earn more money and why some people have billions and we have to save the whole month to get enough from „one to one”. You can also hear questions about how long does it take to work, how much to earn per hour to earn a million ..? The question that comes back frequently is, is wealth the 
result of work and honesty? Finally, what is justice and, frankly speaking, who shapes it and what does it depend on? After all, they ask who has the power and do we, the citizens, have the power? The questions keep multiplying and that is why we often present them with a story that, surprisingly, everyone listens attentively. It has its roots in one of the most interesting monographs by Bronisław Malinowski (Malinowski, 1939).

So we start with the fact that long, long ago, we lived in a clearing surrounded by a beautiful forest ..., when we were hungry, we went hunting, fished and baked what we had obtained on the fire. Of course, we picked fruit, and when we ate it was fun - most often in the evening by the fire. It was warm, the fire gave light, and if someone wanted peace and quiet, he would go to a hut or a nearby cave. Of course, most often not alone. There were so many beautiful girls around, handsome men, there were also uglier or less handsome, but they were looking for someone to cuddle with... The men liked to hug the girls, and so did they to them. At one point it was difficult for the girls' stomachs, but it took a while and after such little or little joy appeared to increase our tribe, it was possible to enjoy cuddling together again. Of course, women with a belly could not go hunting, so they were in the middle of the clearing and always waiting for them great food from the fire. The worst part was that the prettiest girls were busy the most and they walked around with big bellies the most. That is why it was often necessary to wait a long time to cuddle up to such a hug - and there were many willing people in our tribe. We knew that pretty girls are rewarded by the Creator and that is why they have more children as opposed to the slightly less pretty ones - the Creator was not so kind to them. Our life was beautiful, eating, having fun, and hugging and joining in emotional and, above all, physical unity. We lacked nothing but eat, play and lie hugged to our loved one. Of course, there was often a shortage of food in the pre-harvest season, but then we ate what was lost and somehow we managed to survive. We had to deal with it ourselves, without any help.

Everything would be in good health and happiness if it weren't for... Exactly, we did not know that other people lived some days away from us. They were a bit bigger and therefore went hunting more to eat more. Hunting expeditions meant that they had to cover longer distances, which was followed by better condition and strength. And one day they reached our clearing. They saw our 
supplies, girls as well as our laziness and out of condition. They concluded that it is worth taking the loot that is so easy to take. That's what they did, and on the occasion of a few of our people they got hit in the head, and they took many as their slaves. Who of us managed to escape into the depths of the forest was happy. We sat hidden in a hole, covered with leaves. Many climbed trees and still others rushed forward, hoping that the farther the safer. Days, weeks passed, and greater hunger and fear overwhelmed us. We slowly started to come back to our clearing and think what to do. Of course, there were proposals to get out of here and look for a new safe place in the distance. But will it be safe there, or do they sometimes not live there like those who attacked us? Sitting in the evening by the fire, we built various strategies and security procedures. We decided that away from our clearing we should place our tribesmen with the best eyes and ears in the trees. If anyone was approaching, they would let us know so quickly that we could take refuge in the forest. In the evenings, we met with the oldest, most experienced and wisest to talk and look for recipes for survival. There were no such games as before, we lit fires so that no one would notice them, and we slept in sophisticated and difficult to detect places. Time passed and every day during the meetings we wondered how to arrange our future. First of all, we have established round-the-clock duty to ensure the safety of other tribesmen. The management system in our tribe shaped in this way required some actions for the safety of the others, and work from others in order to feed and maintain the former. Therefore, we organized additional warehouses for storing food and we collected and divided this food according to the rules that we adopted during the evening meetings. At one of these evening campfire meetings, the thought occurred to us to send a trusted intent to our enemies and offer them a conversation that would benefit our situation and would also be good for our enemies. Well, our enemies ate the first one sent, but also several more deliberately. However, we did not lose hope, the more that we wanted peace and they would gladly accept a tribute from us. Therefore, at some point their deliberate came to us and presented us with their demands. As a result of many days of hot talks, we came to an agreement. They were stronger than us, and that is why we had to submit to their demands, which boiled down to the fact that we should give them a certain 
number of fish and hunted animals for each inhabitant.For this to be effectively implemented, we have established a foreign representative office with us in the clearing and they are ours with them. It was another or even more people to feed and support, therefore additional duties. And even among our people, there were cases of „sick leave” and even "picking” food and avoiding participating in joint hunts. Although we first worked out decisions together at the meetings of sages, over time, in the face of changes and especially difficulties and the desire to get rich some sloths, we decided that someone should keep an eye on and manage food and set a schedule of duties so as to ensure a fair distribution of duties and goods. We chose such a manager initially every month and then for every year. Therefore, we have created a system that ensures safety for all of us and fairly shares the obligations and resources of the common good (Prandecki, 2016, p. 55 et seq.), Mainly food. With time, a situation developed in which the manager chosen by us began to usurp more and more privileges. He surrounded himself with suckers and temples, who were for him not only a permanent source of information, but also supported him, hoping for additional profits. It was too much and that is why we got rid of our first leader, and after a long evening meeting of our council of sages, we made a new choice (Król, 2017).

\section{IDENTIFICATION OF PARADOXES IN PUBLIC MANAGEMENT}

This dimension of the analysis process conceals the answer to the question of how to operationalize dilemmas through a paradox. the paradigm and what in this paradigm - from the point of view of the essence of this paradox and uncertainty - operationalize.

It is therefore an attempt to find answers to the questions: what are and how are the tensions arising from the disputed issues as a result of the confrontation of two extreme positions, or the clash of two extreme events, views, etc. the actual state of public management in the area of functioning of public administration? and about the effectiveness of this instrument of problem analysis and solution?. 
The nature of a paradox is dual because a paradox is a situation in which two or more mutually exclusive factors are necessary to be considered at the same moment in time. Such a situation implies at least two faces of the same problem, something for something ?, i.e. the simultaneous confrontation of the thesis and antithesis and the need to search - within this confrontation, through the essence of the paradox, the area of its occurrence and the perspective of analysis - synthesis aimed at solving the problem (de Wit., Meyer, 2007). Therefore, decision-makers or managers in the public management process, looking for the best way to solve a given problem, try to mitigate these contradictions as much as possible.

On the one hand, they form the structure of the paradox; permanent choices made by decision-makers and related to the future, on the other hand, the future described as a space burdened with the feature of uncertainty. Thus, a paradox is a conflict resulting from the clash of permanent choices and strategic uncertainty. The paradox is a consequence of the need to make a permanent choice from the range of activities, despite the deep uncertainty as to which one is worth choosing. Persistent choices are the basis of operational activities over time and important factors for development (success) as they make the actions of decision makers difficult to follow. If they are right then everything is OK !!!. However, if they turn out to be - in terms of the future - wrong, missed, it may take a long time for this to be found out, and then their effects will be leveled and new ones will be proposed. Often, in the practice of public management, it is difficult to modify inadequately formulated, undertaken and in the process of implementing permanent choices. This may result in regression. Permanent choices made now, which will turn out in the future - when confronted with the conditions postponed in time (the strategic context) - converge with them, can be assessed as accurate and appropriate. The opposite of them is wrong lasting choices (bad luck?), Often in many ways similar to the right and effective ones. It would be possible to escape the paradox only if the managers constantly made the right and right choices. Unfortunately, in practice (and also in theory), it is not possible for many reasons (Rokita, 2009, Nogalski 2009, pp. 9-27).

So let's get back to our story. Life seemed to be back to normal. We have divided roles in our tribe. Some were hunting, others were fishing, we raised 
our children together. However, due to the need to ensure security, we had to allocate part of our resources to those who could not provide themselves with food. A new structure was developed to manage the resources of the common good. First of all, it was a leader elected by the congregation of sages, whose task was to organize meetings of the sages and the implementation of jointly agreed arrangements. The group fed by everyone also includes the guards of common stocks constituting the resources of the common good, observers placed just in case at a great distance from the clearing, so that they can warn us about the impending danger, foreign, unwanted but necessary representatives of our invaders or women who do not know why bellies often grew. You can see the Great Lord recognized the need to increase the number of tribesmen. There was peace, we returned to the evening bonfires and games, but it was not the carefree as at the beginning. More and more girls were looking for places where there was more good food and, of course, fun. More and more often men had to fight to take just such and not another woman. More and more duties for hunters and hunters and more and more savings of these products - and sometimes even a hunger strike. We all had to pay tribute to functional idlers. But there was no other way out. The worst thing was that our first one on the way to food and other privileges raised his nose higher and higher, surrounded himself with an increasing number of suckers and, worst of all, bribed the most beautiful girls. In his surroundings, efforts were made to build a strong base for our first among those living in our clearing and to give him superhuman qualities, proclaiming him the first after the Supreme. The sect of servants grew in strength and, as a consequence, they shaped absolute power. 


\section{IDENTIFICATION AND DIAGNOSIS OF DILEMMAS ${ }^{1}$ IN PUBLIC MANAGEMENT}

Many years have passed since those wonderful moments, when we talked about everything around the fire, we knew everything about everyone, we had fun together, ate and spent the most beautiful moments joining in the love search for what is the most wonderful in every human life. Later years gave birth to state structures and defined rulers who were given absolute power. Fighting coteries arose around each other, shaping unimaginable hierarchies and values, recognizing only one and their truth, and ordering everyone below to serve this public and alienated authority. Ideology, faith, orders, doctrines, constitutions and the whole machine of perfection of dividing into those who are better born with blood, coming from gods and those in dung, acquired new content and became the undisputed principle of the functioning of societies (Kozłowski, 1991). The only ones who, in their opinion, were able to efficiently manage this whole silly society, were mainly politicians, and the other were subordinated to them, living in the name of faith in a better life but after life. We remember that we raised our heads several times, we had sages, teachers and messengers behind us, He who formed the original relations between us in our common clearing. Always, however, striving for more food, clothes, own lair better than others, and slaves, created a caste imposing such obligations on us that we would build our surroundings and the entire tribe according to not ours, but their expectations. Admittedly, they kept telling us that they wanted us to have everything we want - but the farther away, the more distant these dreams became. The principle that they are to have everything and we are to serve them defined the features of a public management system designed to protect above all those who are above and have a lot, not those in the pits and do not have much (Zimbardo, 2008).

This is how the state management system was shaped, one can accept any state, a state among other states that differ in every respect, but united in maintaining such a status quo in which, on the one hand, there are those who have, and on the other hand, those who give them and themselves have little ( Hongbing, 2010). It must be admitted that in our country, despite many attempts made even in the last 30 years, it has not been possible to 
build what was long, long ago, at least in terms of trust, security, justice and even love. Everywhere we hear that behind our clearing surrounded by forest an enemy is lurking, so we must maintain this state of affairs defined by the resources of the public sector, the tax system necessary to maintain security, the army, the police, but also the army of officials managing this area, which we are not able to perform (Babiński, 2020). Of course, it would be absurd to reject all activities related to building security - this is what many unfavorable rulers of states are waiting for. So the question is what to do? Escape will not help, we will not hide and we will not build an oasis isolated from the surroundings. You can try to change the management system, change the leader. The question is, however, what is the best system and what leader today would be the most effective in protecting us from all kinds of dangers. After all, in order to make a decision, you need to know what decision and why. It will not be a discovery if we emphasize the importance of material goods, not only money, in shaping relations between people, between organizations or countries. Material resources, the desire to influence their increase, hence the rule of power is an incurable disease or a trait, if you prefer (Krokiewicz, Socrates, 2000). This is why it is undertaken in the public sector and universities and science assigned to this sector (after all, there are followers of paradigms that recognize the property of stupefying, dividing into the rich and those who work in companies they create, defining a woman and a man as a resource similar to a stick, car or dollar) (Bieniok, 2006) activities aimed at effectively limiting access to knowledge about money and public finances (Nogalski, Kozłowski, Czaplicka-Kozłowska, 2021) and maintaining the current illegible executive structure of the income and expenditure plan (Kozłowski, Czaplicka-Kozłowska 2014). Also dealing in science with the effects and not the causes of the state of public management (Pearl, Mackenzie, 2018) and building a system of absolute servility and faith in the actions of the highest levels of power. If the highest, in any system based on servility and lack of knowledge of tribesmen, decides that the wearers of trousers and not dresses, or vice versa, are condemned and cannot be allowed to perform certain functions, also having hair color unacceptable or once belonging to the quadruped organization and not two or three-legged, or wearing green rather than black clothes will be considered persona non grata, it will be so. Do we have the right to make mistakes, the right to correction, the right to sin and 
repentance, or do we have the right to make mistakes only to those closest to the great leader of the tribe? Of course, we were not and we are not perfect, in our life it was different, sometimes stupid, sometimes a bit smarter - but a medal to those who objectively say what was right and what was wrong in our behavior. Should anyone with many women or anyone with many men be cursed? If one belonged to the perverse party (and there were many of them left and right) that turned the system upside down, then today it is considered by some as bad or by others as good - tomorrow it may be considered the other way around. One has to ask, however, if the nation was oppressed, do monuments belong? Life is a collection of different behaviors and our current judgments are tainted with our present knowledge, our present beliefs, and often comfort, and perhaps that is why we have become a collection of uncritical members in the supreme leader party (Griffin, 1996). It is he, our chosen one, who has the most important and righteous qualities - he is one great ideal and what distinguishes us from our king, secretary, president or other ruler is our fault.

\section{RECOMMENDATIONS FOR SOLUTIONS TO IMPROVE PUBLIC MANAGEMENT}

We should always ask ourselves what is right and what is wrong. We should seek answers to all questions and, as teachers, try to answer them on the basis of personally conducted research or the research of scientists in the fields covering the problem area. Listening to the statements of many people behind scientific titles, we ask ourselves the basis on which these views are expressed - has he conducted any research, published them and are they the result of his scientific investigations? Or is it just a conveyor of information drawn up by organizations interested in obtaining certain benefits (the publisher of such views counts on profits on this account)? Very often, people with scientific titles, who express views in the interest of politicians or interest groups, e.g. business interest groups, express an opinion that undermines the results of research, stating: who what he knows is just nonsense, on what basis this opinion, where research, analysis, comparisons - where is the science on the basis of which such an opinion can be expressed? Academic teachers 
recognized by the circles of interests are always right and appreciated in the opinion of some, and those who advocate other views are never right. It is the achievement of science for many to find something new by someone who receives a lot in order to undermine the obvious that is the barrier to achieving more, more and more.

Conducting research very often forgets what was, what shaped a woman and a man, what shaped relationships between people and between tribes. Today's times are usually described by "gurus of science”, authorities and experts who often base their opinions on a more or less filled envelope or payment or salary. Therefore, it is worth looking for an answer to the question of what is money in human life, why our universities were so high and now they are so low, and why only English publications count and who built it all this way. Finally, it is worth knowing the history and looking for an answer to the question why is this so? Perhaps it is history textbooks, such as the history of money and finance, those in primary school primarily as well as in high school and college, that should be based on in-depth scientific research and not someone's arguments, opinions and wishes.

When conducting classes, we emphasize, referring to many authors, including our own studies, that management means the process of planning, organizing, leading and controlling the work of organization members and using all available resources of the organization to achieve its goals (Stoner, Freeman, Gilbert, 2001, p. .603). When recalling the classics relating to management, it should be noted that it is important to pay attention to the role of people in charge of organizations, to distinguish between causes and effects, and to the knowledge of public sector leaders and citizens. The world that passed away in Poland at the turn of the 1980s and 1990s was characterized by the government's desire to enslave people. That is why the access to knowledge was limited, and if it was passed on, its content was far from the truth and was used to build the wealth of the chosen ones. In order for the bygone times not to come back, it is necessary to base public management on paradigms shaped in science based on researching the causes of phenomena in the surrounding real world. The basis of management is the creation of a world accepted by organized communities, a world friendly to members of the organization, fair and valuing the basic human values. 


\section{Conclusion}

Analyzing the reality that surrounds us, including the new approach to public management and within it to strategic management, one can notice many unfavorable phenomena and activities aimed at eliminating the paradigms of management science. Going back to the primeval times and referring it to our tradition, it can be seen that in our culture founded on years of history, the mayor, head of the village or the starost are primarily people called „wise”. Recent years have changed this, and most often people performing public functions, thus managing public sector organizations, often perform tasks and achieve goals that differ from what is accepted and desired by members of these organizations. In the public sector, „management” (understanding this concept) hardly makes its way in public institutions and is most often associated with the economy and enterprises (Zawicki, Mazur, Bober, 2004, pp. 14-15). As the research and observations conducted by the authors of the study show, management in the public sector is often determined by the struggle for domination between particular parties, politicians or persons performing public functions. If a few years ago you could meet representatives of public sector organizations at various levels at scientific conferences, now this phenomenon is an exception and the conducted research, results of these studies and recommendations that critically describe the surrounding reality are rejected. Therefore, showing the surrounding reality during classes in schools and universities, as well as relating it to history and emphasizing the resulting paradigms seems most appropriate. 


\section{REFERENCES}

Babiński, A. (2020). W poszukiwaniu definicji bezpieczeństwa Publicznego. Zeszyty Naukowe Państwowej Wyższej Szkoły Zawodowej im. Witelona w Legnicy, 2 (35), s. 91-109.

Bieniok, H. (red.). (2006). System zarzadzania zasobami ludzkimi przedsiębiorstwa, Katowice: Wydawnictwo Akademii Ekonomicznej Im. Karola Adamieckiego w Katowicach.

de Wit, B., Meyer, R. (2007). Synteza strategii. Tworzenie przewagi konkurencyjnej poprzez analizowanie paradoksów. Warszawa: PWE.

Dobrowolski, Z., (2013). Debata publiczna jako instrument usprawniania zarządzania organizacjami publicznymi. Studia Lubuskie, T.9, s. 127-142.

Griffin, R. W. (1996). Podstawy zarządzania organizacjami, Warszawa: PWN.

Hongbing, S. (2010). Wojna o pieniadz 1. Prawdziwe źródła kryzysów finansowych, Bielany Wrocławskie: Wydawnictwo Wektory.

Krokiewicz, A., Sokrates. (2000). Etyka Demokryta i hedonizm Arystypa, Warszawa: Alethela.

Król, M. (2017). Jaka demokracja? Warszawa: Wydawnictwo AGORA.

Kozłowski, A. J. (1991). Kadra kierownicza administracji państwowej. Ostrołęka: Ostrołęckie Towarzystwo Naukowe.

Kozłowski, A. J., Czaplicka-Kozłowska, I. Z. (2014). Transparentność zarządzania finansami lokalnymi. Uwarunkowania wdrożenia planu dochodów i wydatków w układzie zadaniowym. Wałbrzych: Oficyna Wydawnicza „Impuls” w Krakowie, dla QNT Systemy Informatyczne Sp. z o.o.

Kożuch, B. (2005). Istota zarządzania publicznego. Problemy Zarządzania, Warszawa: Wydawnictwo Wydział Zarządzania UW, 4/2005 (10), s.40-50.

Malinowski, B. (1939). Życie seksualne dzikich w pótnocno-zachodniej Melanezji, Warszawa: Wydawnictwo J. Przeworskiego.

Nogalski, B. (2009). Paradoks strategii jako propozycja operacjonalizacji paradygmatu rozwoju przedsiębiorstwa w warunkach niepewności i zmian. W: J. Rokita (red.). Zarządzanie w warunkach nieprzewidywalności zmian, Katowice: Górnośląska Wyższa Szkoła Handlowa im. Wojciecha Korfantego.

Nogalski, B., Kozłowski, A. J., Czaplicka-Kozłowska, I. Z. (2021). Bezpieczeństwo finansowe a wiedza o pieniądzu i finansach - jako element podnoszenia jakości zarządzania finansami. W: S. Tkaczyk, T. Wawak (red.). Stan i perspektywy rozwoju jakości w XXI wieku : rozwiązania i dylematy: księga jubileuszowa z okazji 45-lecia pracy naukowej profesor Elżbiety Skrzypek, Lublin: Wydawnictwo Uniwersytetu Marii Curie-Skłodowskiej.

Pearl, J.; Mackenzie, D. (2018). Przyczyny i skutki, Rewolucyjna nauka wnioskowania przyczynowego, Kraków: Copernicus Center Press. 
Prandecki, K. (2016). Dobro wspólne a zrównoważony rozwój. Optimum. Studia Ekonomiczne, 4 (82), s. 55-68.

Rokita, J. (2009). Dynamika zarządzania organizacjami. Katowice: Prace Naukowe Akademii Ekonomicznej im. Karola Adamieckiego w Katowicach.

Stoner, J. A. F., Freeman, R .E., Gilbert, D. R. (2001). Kierowanie, Warszawa: PWE. Wielki słownik języka polskiego (2018). Warszawa: PWN.

Zawicki, M, Mazu, S., Bober, J. (2004). Zarzadzanie w samorządzie terytorialnym. Najlepsze praktyki. Kraków: Wyd. Małopolska Szkoła Administracji Publicznej Akademii Ekonomicznej w Krakowie oraz MSWiA.

Zimbardo, F. (2008). Efekt Lucyfera, Dlaczego dobrzy ludzie czyniq zło?. Warszawa: PWN.

\section{ENDNOTES}

1 A dilemma is a problem the solution of which lies in the difficult choice between two equally important reasons. (Wielki słownik języka polskiego, 2018). 
